Fakt mylenia tak ważnych informacji w trakcie przeprowadzania wywiadu kierowanego pozostawia wiele do życzenia i każe zastanowić się czy Autorka opanowała w pełni warsztat metodologiczny.

Występujące w książce błędy merytoryczne podważają w opinii autorki recenzji wiarygodność pozycji książkowej I. Jakimowicz-Ostrowskiej, a treści dotyczące szkolnictwa mniejszości narodowych i etnicznych w województwie gdańskim są nieprawdziwe, przez co bezwartościowe. Wydaje się jednak, że po rozpoznaniu przez Autorkę tematyki historyczno-oświatowej i znaczącej korekcie treści, wydanie drugie, poprawione może stanowić ciekawą pozycję naukową.

Lidia Burzyńska-Wentland

\title{
Stownik biograficzny twórców oświaty i kultury XIX i XX wieku Polski potu- dniowo-wschodniej, pod red. Andrzeja Meissnera i Kazimierza Szmyda, Wyd. Uniwersytetu Rzeszowskiego, Rzeszów 2011, ss. 494
}

W 2011 r. nakładem wydawnictwa Uniwersytetu Rzeszowskiego ukazał się Słownik biograficzny twórców oświaty $i$ kultury XIX $i$ XX wieku Polski potudniowo-wschodniej, pod red. Andrzeja Meissnera i Kazimierza Szmyda. Jak podają redaktorzy idea przygotowania tego typu wydawnictwa pojawiła się w rzeszowskim środowisku naukowym już w latach sześćdziesiątych XX w. Wówczas inicjatywę przygotowania słownika obejmującego biogramy działaczy społecznych województwa rzeszowskiego podjął pracownik naukowy Wyższej Szkoły Pedagogicznej w Rzeszowie Stanisław Frycie. Niestety publikacja ta nie ukazała się drukiem ze względu na zastrzeżenia ze strony władz. Ponad pół wieku później rzeszowski ośrodek naukowy, już jako Uniwersytet Rzeszowski, powrócił do tej idei. Jej realizacji podjęli się pracownicy Zakładu Historii Oświaty i Wychowania wraz z licznym gronem współpracowników.

Ostatecznie w pracach nad przygotowaniem tej publikacji uczestniczyło ponad 100 osób reprezentujących nie tylko środowiska naukowe, ale także podkarpackie instytucje kulturalno-oświatowe (biblioteki, muzea, szkoły średnie, archiwa czy różnorodne towarzystwa). Wśród autorów biogramów odnajdujemy m.in. pracowników naukowych Uniwersytetu Rzeszowskiego oraz Politechniki Rzeszowskiej, Uniwersytetu Jagiellońskiego, Katolickiego Uniwersytetu Lubelskiego, Uniwersytetu Marii Curie Skłodowskiej w Lublinie, Uniwersytetu Wrocławskiego czy Politechniki Śląskiej. Swój wkład w przygotowanie Słownika wnieśli także archiwiści związani zarówno z archiwami centralnymi (m.in. Archiwum Głównym Akt Dawnych w Warszawie), jak i regionalnymi oraz bibliotekarze i muzealnicy.

Zaproponowana w latach sześćdziesiątych XX w. koncepcja słownika uległa jednak zasadniczym zmianom i została ograniczona do prezentacji biogramów osób związanych z działalnością kulturalną i oświatową. Ostatecznie Słownik prezentuje sylwetki blisko 
700 osób - są wśród nich ,animatorzy życia kulturalnego, profesjonalni i ludowi twórcy i odtwórcy kultury, dziennikarze, bibliotekarze, wydawcy, księgarze, drukarze, pisarze, pamiętnikarze, malarze, rzeźbiarze, muzycy, kompozytorzy, muzealnicy, archiwiści, etnografowie, twórcy fotografii artystycznej, działacze oświaty, organizatorzy placówek edukacyjnych, przedstawiciele różnych zawodów zaangażowani w działalność kulturalno-oświatową"

Redakcja Słownika za wzór przy opracowywaniu biogramów przyjęła Polski słownik biograficzny. Zakres chronologiczny wydawnictwa obejmuje okres blisko 250 lat - od schyłku wieku XVIII do czasów współczesnych, terytorialnie natomiast ograniczono się przede wszystkim do obszaru dzisiejszego województwa podkarpackiego. Przyjęto także wyraźne kryteria kwalifikowania poszczególnych biogramów. Jak zaznaczyli redaktorzy w Słowniku „uwzględniono osoby działające na obszarze regionu zarówno pochodzące z Podkarpacia, jak i przybyłe na ten teren. Pominięto natomiast osoby, które urodziły się na Podkarpaciu, ale działały w innych regionach Polski. Intencją autorów Słownika [...] jest bowiem ukazanie postaci zasłużonych dla regionu, lecz dotąd nieodnotowanych w podobnych wydawnictwach. Pewien wyjątek uczyniono dla osób, które wywodziły się z Podkarpacia i działały poza tym terenem, lecz nie zerwały kontaktów z miejscem pochodzenia i podejmowały działania na rzecz „małej ojczyzny”2.

Do każdego z biogramów prezentowanych na kartach Słownika dołączona została bibliografia obejmująca przede wszystkim źródła archiwalne oraz drukowane. Autorzy poszczególnych biogramów sięgali jednak także do źródeł internetowych oraz wywołanych, przeprowadzając liczne wywiady.

Słownik uzupełniaja, typowe dla tego rodzaju wydawnictw, wykazy skrótów oraz wykazy autorów poszczególnych biogramów określające reprezentowaną przez nich instytucję.

Czytelnik sięgający do tej publikacji odnajdzie w zamieszczonych w niej biogramach ślady wielokulturowości i wieloetniczności regionu podkarpackiego. Przedstawione tam postaci reprezentują różnorodne grupy społeczne, wyznaniowe czy zawodowe - łączy jej jednak przynależność do grona twórców istotnych, nie tylko dla tamtych terenów Polski, tradycji kulturalno-oświatowych. Stanowią oni ważny element w utrwalaniu tożsamości lokalnej mieszkańców Podkarpacia.

Warto w tym miejscu przytoczyć konkretne przykłady. Wydawnictwo otwiera biogram Mieczysława Zygmunta Adamowskiego (1892-1975) - nauczyciela i bibliotekarza, autora wielu naukowych prac z dziejów oświaty galicyjskiej, tłumacza poezji greckiej oraz prezesa Towarzystwa Regionalnego Ziemi Rzeszowskiej. Ostatnią postacią prezentowaną na kartach Stownika jest natomiast żyjący w latach 1888-1963 artysta plastyk i nauczyciel rysunku, absolwent krakowskiej Akademii Sztuk Pięknych Władysław Żurawski, którego prace wielokrotnie pojawiały się na wystawach organizowanych zarówno w okresie międzywojennym, jak i po zakończeniu II wojny światowej. Należy także zaznaczyć, że biogram Żurawskiego został przygotowany przede wszystkim w oparciu

\footnotetext{
${ }^{1}$ Stownik biograficzny..., s. 7.

2 Ibidem, s. 8.
} 
o materiały archiwalne zawierające m.in. zbiór dokumentów osobistych i rodzinnych tego twórcy.

Jak wynika z zamieszczonego w Słowniku „Wstępu” redaktorzy planują w przyszłości nie tylko opublikowanie suplementu, ale także wydanie kolejnego tomu poświęconego tym razem ludziom nauki z tamtych terenów - a zatem pracownikom uczelni wyższych, instytucji naukowych oraz nauczycielom.

Agnieszka Wałega

\section{Stownik biograficzny nauczycieli Wielkopolski Wschodniej, red. P. Gołdyn, t. I, Konin 2012, ss. 300}

Losy człowieka wiodą przez szkołę, którą tworzą nauczyciele i uczniowie oraz zachodzące pomiędzy nimi interakcje. Mogą one mieć decydujący wpływ na ich dalszą drogę życiową. Każda jednostka, uczestnicząc w procesie edukacyjnym, spotkała na swojej drodze wielu nauczycieli, którzy mieli własny styl porozumiewania się z uczniami, indywidualne metody, formy oraz środki przekazu wiedzy. Jednakże wraz z upływem lat, absolwenci nie pamiętają swoich „mistrzów”. Chcąc ocalić od zapomnienia ich działalność, na rynku wydawniczym pojawiło się wiele prac biograficznych, przedstawiających życie nauczycieli, uczonych, zasłużonych dla polskiej nauki. Są to publikacje tak w formie słownikowej ${ }^{1}$, jak i w postaci opracowań monograficznych. Jednakże niewiele z nich dotyczy danego terenu czy określonego regionu². Dlatego Słownik biograficzny nauczycieli Wielkopolski Wschodniej uzupełnia dotychczasową wiedzę w tym zakresie. Powstał on dzięki współpracy konińskiego Ośrodka Doskonalenia Nauczycieli z Publicz-

\footnotetext{
${ }^{1}$ Przykładowe słowniki biograficzne to m.in.: A. Gąsiorowski (red.), Historia wychowania: słownik biograficzny, Olsztyn 1994; W. Korzeniowski (red.), Słownik biograficzny historii myśli pedagogicznej, BielskoBiała 2006; Cz. Kupisiewicz i M. Kupisiewicz, Poczet wybitnych nauczycieli, t. I i II, Pułtusk 2006; A. Meissner, Stownik biograficzny twórców oświaty i kultury XIX i XX wieku Polski Poludniowo-Wschodniej, Rzeszów 2011; A. Meissner, W. Szulakiewicz (red.), Stownik biograficzny polskiej historii wychowania: praca zbiorowa, Toruń 2008; H. Tadeusiewicz, Słownik biograficzny Wielkopolski Południowo-Wschodniej: ziemi kaliskiej, Kalisz 1998.

2 Jako przykład słowników biograficznych nauczycieli pracujących na określonym terenie można wymienić: J. Chrobaczyński (red.), Słownik biograficzny nauczycieli w Małopolsce w latach II wojny światowej (1939-1945): ofiary wojny, żotnierze, działacze konspiracyjni, nauczyciele w jawnym i tajnym szkolnictwie, Kraków 1995; J. Doroszewski (red.), Słownik biograficzny nauczycieli miasta Lublina w latach 1918-1939, Lublin 2007; J. Duda, A. Szelka, F. Dzionek (red.), Stownik biograficzny nauczycieli Ślaska Opolskiego, t. 1-6, Opole 1995; W. Prarat (red.), Stownik biograficzny nauczycieli szkót powszechnych gminy Gorzyce do I połowy XX wieku, Sandomierz 2007; A. Massalski (red.), Słownik biograficzny: nauczyciele szkót średnich rzqdowych męskich w Królestwie Polskim 1833-1862, Kielce 2007; A. Massalski, Stownik biograficzny zastużonych nauczycieli $i$ wychowanków: I Liceum Ogólnokształcqce im. Stefana Żeromskiego w Kielcach, Kielce 2010.
} 